\title{
Najnowsze publikacje dotyczące historii Krymu okresu II wojny światowej
}

Zarys treści: Artykuł prezentuje trzy najnowsze publikacje dotyczące historii kolaboracji Tatarów Krymskich z Niemcami w latach 1941-1944. O ile praca O. Romańki jest wyważoną próbą opisania i oceny tego zjawiska, o tyle pozostałe dwie książki (autorstwa A. Malgina i G. Bekirowej) należy rozpatrywać w kontekście sporu politycznego, jaki toczy się na Krymie od ponad 20 lat. Na przykładzie tych opracowań opisana jest specyfika krymskiej przestrzeni informacyjnej dominacja sowiecko-rosyjskiej wizji historii oraz ograniczenia blokujące dialog rosyjsko-tatarski i pracę niezależnych historyków.

Słowa kluczowe: historia Krymu w czasie II wojny światowej, Tatarzy Krymscy, kolaboracja, historia II wojny światowej, ZSRR

Keywords: The Crimea during the Second World War, Crimean Tatars, collaboration, World War II, history of the USSR

Historia Krymu przyciągała i przyciąga nadal przede wszystkim badaczy epoki nowożytnej. Dużym zainteresowaniem cieszy się także kompleks spraw związanych z geopolityczną rolą Krymu po rozpadzie ZSRS i przemianami społeczno-politycznymi, jakie zaszły tam w ciągu ostatniego ćwierćwiecza, przy czym tematyką tą zajmują się nie tyle historycy, ile politolodzy i analitycy stosunków międzynarodowych. Wewnętrzne dzieje półwyspu w ciągu XIX i XX w. pozostają przy tym trochę zaniedbane przez badaczy. Sytuacja ta uległa pewnej poprawie w ciągu ostatnich kilku lat, kiedy to ukazało się w Rosji i na Ukrainie kilka godnych uwagi prac. Wymienić tutaj należy m.in. monografię wojny domowej na Krymie lat 1917-1920 autorstwa braci Zarubinów ${ }^{1}$, prace Olega Romańki i Andrieja Malgina dotyczące

1 А. Г. Зарубин, В. Г. Зарубин, Без победителей. Из истории Гражданской войны в Крыму, Симферополь 2008. 
okresu okupacji niemieckiej ${ }^{2}$ czy zarys historii politycznej Tatarów Krymskich po II wojnie światowej Gulnary Bekirowej ${ }^{3}$.

Chociaż publikacje te w znaczący sposób uzupełniły dotychczasową, skromną bibliografię historii Krymu XIX i XX w., to jednak często ich poziom pozostawia wiele do życzenia, zwłaszcza w porównaniu z nielicznymi książkami z tej tematyki, które wyszły spod pióra historyków zachodnich. Jest to, swoją drogą, sytuacja typowa dla historiografii całego północnego pobrzeża Morza Czarnego. Region ten pozostaje od lat w głębokim kryzysie gospodarczym i społecznym, co rzutuje także na stan nauki. Przyczyn tego należy upatrywać przede wszystkim w powolnym tempie desowietyzacji historii, zarówno pod względem ideologicznym, jak i organizacji badań naukowych ${ }^{4}$.

Biorąc pod uwagę, że rozpiętość chronologiczna i złożoność tematu nie pozwalają na przybliżenie w zwięzłej formie polskiemu czytelnikowi problematyki wszystkich wymienionych monografii, ograniczę się do omówienia zagadnienia kluczowego dla historii Krymu XX w. Jest nim okupacja półwyspu przez Niemców w latach 1941-1944 i jej bezpośrednie następstwa - wymordowanie bądź deportacja ponad 1/3 przedwojennej ludności półwyspu, a w efekcie całkowita zmiana dotychczasowej struktury etnicznej i lokalnej specyfiki Krymu. Chciałbym nie tylko przedstawić trzy główne punkty widzenia na te wydarzenia, reprezentowane w pracach Malgina, Romańki i Bekirowej, ale też omówić kwestię ograniczeń pracy historyka w realiach dzisiejszego Krymu oraz pokazać, do jakiego stopnia wydarzenia sprzed 70 lat dzielą miejscowe społeczności i jak instrumentalnie są wykorzystywane w bieżącej walce politycznej.

Po nieudanych próbach utworzenia państwa krymskiego w 1918 r. nastąpił okres dwuletniego wyniszczenia półwyspu w trakcie wojny domowej. Bolszewicy zajęli Krym dopiero jesienią 1920 r. i wkrótce potem zdecydowali się na utworzenie Krymskiej Autonomicznej Socjalistycznej Republiki Sowieckiej w ramach Rosyjskiej Federacyjnej Socjalistycznej Republiki Sowieckiej. Tatarom przyznano koncesje w zakresie szkolnictwa, kultury i języka w okresie tzw. „korenizacji”. Później historia

2 А. В. Мальгин, Партизанское движение Крыма и «татарский вопрос» 1941-1944, Симферополь 2009; О. В. Романько, Крым под пятой Гитлера. Немеикая оккупационная политика в Крыму 1941-1944 г2., Москва 2011.

3 Г. Бекирова, Крымские Татары 1941-1991, Симферополь 2008.

Poza wymienionymi książkami w ciągu ostatnich lat ukazało się też kilka pozycji dotyczących historii Tatarów, Niemców, Greków, Bułgarów, Ormian i Żydów, z których wyróżnia się monografia Żydów (wraz z Krymczakami i Karaimami) autorstwa Michaiła Kiziłowa (Крымская Иудея. Очерки истории евреев, хазар, караимов и крымчаков в Крыму с античных времен до наших дней, Симферополь 2011).

4 Nadal najlepszą syntezą historii półwyspu pozostaje książka amerykańskiego historyka Alana Fishera sprzed 35 lat (A. Fisher, The Crimean Tatars, Stanford 1978); zob. też wybór jego artykułów Between Russians, Ottomans and Turks, Istanbul 1998.

Chyba jeszcze wyraźniej niż w przypadku Krymu, tendencja ta widoczna jest w historiografii Odessy, gdzie prawie wszystkie wartościowe monografie $\mathrm{z}$ historii miasta i regionu w XIX i XX w. ukazały się w języku angielskim i ewentualnie dopiero później zostały przetłumaczone na rosyjski bądź ukraiński. 
autonomii krymskiej nie odbiegała zasadniczo od historii innych republik. Tuż po przejęciu władzy przez bolszewików i pod koniec lat 20. nastąpiły masowe represje wobec przedstawicieli tatarskiej elity narodowej i duchowieństwa, dalej kolektywizacja i kolejna fala represji pod koniec lat 30 . Zniszczenie dawnego modelu gospodarki, dezorganizacja produkcji rolniczej i rekwizycje skutkowały głodem w latach 1921-1923, który pochłonął życie ok. 100000 mieszkańców półwyspu (szczególnie silnie dotknął małorolne gospodarstwa tatarskie w górskiej i wyżynnej części półwyspu). Druga fala głodu powtórzyła się na początku lat 30. Przy tym wszystkim władze sowieckie prowadziły politykę przekształcenia Krymu w „związkowe uzdrowisko” i tworzenia przemysłu poza wybrzeżem, co wiązało się z napływem tysięcy nowych pracowników z głębi ZSRS. Ludność półwyspu po 20 latach rządów sowieckich mimo emigracji, klęsk głodu i masowych represji - wzrosła o ok. 300000 ludzi, przy czym stale spadał odsetek Tatarów (z niecałych 30\% do niecałych 20\% w 1939 r.) $)^{5}$. Biorąc do tego pod uwagę różnice językowe i obyczajowe, nie dziwi fakt, że stopień utożsamienia się Tatarów z państwem sowieckim w momencie wybuchu wojny nie był duży. Jak słusznie podsumował te zagadnienia w omawianej monografii Oleg Romańko: „władza sowiecka zrobiła wszystko, co można było zrobić dla wywołania kryzysu lojalności wobec siebie wśród Tatarów Krymskich” (s. 129).

Jesienią 1941 r. wojska niemieckie bez większych problemów sforsowały Przesmyk Perekopski i zajęły przeważającą część półwyspu; Armii Czerwonej udało się na dłużej utrzymać jedynie w Sewastopolu, który jako odcięta twierdza bronił się aż do lata 1942 r. Zdając sobie sprawę z konieczności ustąpienia z Krymu wobec sukcesów ofensywy niemieckiej na sąsiednich frontach, dowództwo sowieckie przygotowało plany organizacji kilku zgrupowań partyzanckich i zawczasu przygotowało dla nich broń i zaopatrzenie. Miały one operować głównie w Górach Krymskich - jedynym terenie dogodnym dla prowadzenia wojny partyzanckiej. Był to jednocześnie obszar zamieszkany w zdecydowanej większości przez Tatarów. W skład oddziałów partyzanckich mieli wchodzić członkowie partii komunistycznej, zmobilizowani mieszkańcy okolicznych wsi, żołnierze z rozbitych oddziałów Armii Czerwonej oraz funkcjonariusze NKWD.

Wkraczające jednostki Wehrmachtu były nie tylko przyjaźnie witane we wsiach tatarskich, ale też ich ludność od samego początku aktywnie i samorzutnie pomagała Niemcom w charakterze przewodników, wyłapywała pojedynczych rozbitków Armii Czerwonej i rozkradała pozostawione w lasach dla partyzantów bazy zaopatrzeniowe. Bardzo szybko, jeszcze w czasie trwania regularnych działań wojennych, w wyniku

5 Przed wybuchem wojny krymskiej w połowie XIX w. Tatarzy stanowili ok. 3/4 ludności półwyspu (łącznie ok. 350 000). Wg spisu powszechnego z 1897 r. półwysep zamieszkiwało ok. 550000 ludzi, z czego ok. 36\% Tatarów Krymskich, 33\% Rosjan, 12\% Ukraińców, 6\% Niemców, 4,5\% Żydów, 3\% Greków.

W 1917 r. ludność Krymu (w dużym przybliżeniu) wynosiła ponad 800000 ludzi, przy czym odsetek Tatarów spadł już poniżej 30\%. W 1939 r. na Krymie mieszkało ok. 1124000 ludzi, z czego prawie 50\% Rosjan, prawie 20\% Tatarów, ok. 14\% Ukraińców, 6\% Żydów, 4,5\% Niemców, 2\% Greków. Dane wg Население Крыма в конце XVIII - конце XX веков, ред. Я. Е. Водарский, Москва 2003. 
oddolnej inicjatywy niemieckich oficerów, w wybranych wsiach powstały niewielkie oddziały „samoobrony” tatarskiej. Niemcy początkowo traktowali tych ochotników ostrożnie - byli oni nieumundurowani, nie otrzymywali wynagrodzenia i wydawano im zdobyczną broń sowiecką jedynie na czas pełnienia służby. Równolegle pod koniec 1941 r. w Bachczysaraju powstał pierwszy tzw. komitet muzułmański, który miał zajmować się organizacją pomocy społecznej, szkolnictwa, życia kulturalnego i religijnego. Wkrótce po nim powstały podobne komitety w innych miastach i Tatarzy zaczęli domagać się, aby komitet symferopolski stał się ich centralną reprezentacją polityczną. Postulaty te spotkały się ze zdecydowaną odmową. Następnie w ciągu pierwszego półrocza 1942 r. Niemcy, po nabraniu większego zaufania do oddziałów „samoobrony”, zdecydowali się przeprowadzić szerszą akcję werbunku wśród Tatarów. W jej wyniku napłynęło ok. 15000 ochotników miejscowych i Tatarów Krymskich zwerbowanych w obozach jenieckich. Większość z nich porozdzielano do walczących pod Sewastopolem oddziałów Wehrmachtu, z reszty sformowano sieć posterunków lokalnej policji podległej władzom administracyjnym, a z ok. 1600 sformowano kompanie „samoobrony” podlegające władzom policyjnym. Kompanie te były już jednolicie umundurowane i uzbrojone, stacjonowały w poszczególnych wsiach dla zwalczania partyzantki. Czynnik narodowy i religijny w tworzeniu tych oddziałów wyszedł na pierwszy plan - żadna inna grupa narodowa na Krymie nie tworzyła wówczas podobnych formacji ani nie współpracowała z Niemcami w tak zorganizowany sposób.

Równocześnie pojawiły się ze strony tatarskiej kolejne postulaty w sferze politycznej - reaktywacji Narodowej Partii Tatarskiej (czyli Milli Firka, zdelegalizowanej przez bolszewików tuż po przejęciu władzy na Krymie w 1920 r.), zwołania parlamentu (Kurułtaju) i utworzenia państwa krymskiego pod niemieckim protektoratem. Uaktywniła się w tym kierunku także emigracja, usiłująca zdobyć sobie status reprezentacji politycznej Tatarów Krymskich w Berlinie. Wszystko to spotkało się ze zdecydowanym sprzeciwem Niemców, którzy konsekwentnie stali na stanowisku utrzymania ścisłej separacji między emigracją a działaczami tatarskimi na Krymie oraz ograniczenia działalności komitetów muzułmańskich do roli lokalnych instytucji dobroczynnych i kulturalnych, nawet bez utworzenia nad nimi ogólnokrymskiego zwierzchnictwa.

Tymczasem w górach trwała zażarta walka partyzantów o przeżycie. Ich oddziały na początku dotknęła fala dezercji, a wobec likwidacji prawie wszystkich baz zaopatrzeniowych i zdecydowanie wrogiej postawy okolicznych wsi, już po kilku miesiącach stanęło przed nimi widmo głodu. Krytyczna sytuacja zaczęła się wiosną 1942 r., kiedy zdarzyły się pierwsze przypadki śmierci głodowej wśród partyzantów (mówiono nawet o przypadkach kanibalizmu). Apogeum kryzysu nastąpiło latem 1943 r., kiedy to w górach utrzymały się grupki liczące łącznie zaledwie 200-300 ludzi, przeważnie wycieńczonych i niezdolnych do jakiekolwiek aktywności ofensywnej. Unieszkodliwienie partyzantki było możliwe tylko i wyłącznie dzięki pomocy miejscowej ludności. Jak zawsze przy tego typu nieregularnych działaniach, doszło 
do brutalizacji wojny i rozszerzenia walki na całą społeczność cywilną. Z jednej strony partyzanci musieli zdobyć żywność - jeżeli nie dostawali jej dobrowolnie albo sprowadzano na nich oddział karny po przeprowadzeniu rekwizycji, wieś stawała się automatycznie ich śmiertelnym wrogiem. Drugi scenariusz zakładał nawiązanie współpracy z partyzantką (dobrowolnej czy pod przymusem) i wieś stawała się z kolei wrogiem Niemców i ich sojuszników. Oddziały partyzanckie składały się przeważnie z Rosjan (z dużym odsetkiem Ukraińców, Białorusinów i Żydów), wsie górskie były w zdecydowanej większości zamieszkane przez Tatarów i w takich okolicznościach walka z partyzantką szybko przekształciła się w lokalny konflikt etniczny rosyjsko-tatarski. Niemcy traktowali współpracę z Tatarami instrumentalnie (co pokazał ich stosunek do komitetów muzułmańskich) i dopiero w lecie $1943 \mathrm{r}$. zdali sobie sprawę z niebezpieczeństwa wciągnięcia społeczeństwa rosyjskiego na Krymie (dotychczas raczej biernego) w ten konflikt po stronie sowieckiej. Wykonali wówczas kilka gestów mających pozyskać ich sympatię i ogłosili nabór do pododdziałów formowanych pod szyldem Rosyjskiej Armii Wyzwoleńczej gen. Własowa, co jednak przyniosło bardzo mizerne rezultaty.

Sukcesy w walce z partyzantką w ciągu pierwszego półrocza 1942 r. spowodowały, że Niemcy zdecydowali się na jeszcze większe rozwinięcie oddziałów tatarskich. Drogą zaciągu ochotniczego i przeniesienia części ludzi z pododdziałów pomocniczych Wehrmachtu, utworzyli w X 1942 r. osiem batalionów Schuma stacjonujących w najważniejszych miastach Krymu, skoszarowanych (a nie rozkwaterowanych po wsiach, jak istniejące cały czas kompanie „samoobrony”), jednolicie umundurowanych, z pełną tatarską obsadą oficerską, dysponujących etatową bronią maszynową i nawet moździerzami. Większość z nich miała stanowić odwody, zdolne do udzielenia szybkiej pomocy kompaniom „samoobrony”, znajdującym się w pierwszej linii walki z partyzantką (poza tym pełniły też częściowo funkcje wartowniczo-patrolowe, m.in. w obozach jenieckich i koncentracyjnych). Wszystko to świadczyło o dużym zaufaniu, jakim Niemcy obdarzyli formacje tatarskie. Jak pokazały wydarzenia z przełomu 1943/1944 r. Tatarzy raczej ich nie zawiedli - w świetle dość ogólnych danych wydaje się, że poziom dezercji w oddziałach tatarskich w trakcie ostatnich walk na Krymie był niższy, niż w pozostałych oddziałach obcoplemiennych. Prawdopodobnie ok. 2500 żołnierzy tatarskich udało się Niemcom ewakuować drogą morską (później starano się jeszcze użyć ich na froncie). Partyzantka dopiero w drugiej połowie 1943 r. - dzięki postępom Armii Czerwonej na froncie i uzyskaniu wzmocnienia w ludziach i sprzęcie - zaczynała się rozbudowywać, prowadzić działania ofensywne i udało jej się w ostatniej fazie zająć większe obszary w strefie pogórza.

Nawet wobec zmienionej sytuacji na froncie, Niemcy w zasadzie do końca nie zdecydowali się na wyzyskanie czynnika tatarskiego (i szerzej muzułmańskiego) na płaszczyźnie politycznej. Do końca okupacji Krymu nie zdobyli się na udzielenie Tatarom konkretnych obietnic politycznych ani na reaktywację muftiatu krymskiego, mimo utworzenia przez Moskwę dla celów propagandowych stanowiska głównego muftiego ZSRS. Tatarzy, wbrew początkowym nadziejom, zostali wykorzystani 
pod względem wojskowym, nie dostając w zamian żadnych koncesji politycznych. Pozbawieni kierownictwa politycznego, zostali jednocześnie pozbawieni możliwości elastycznego reagowania na sytuację, podczas gdy na szczeblu lokalnym konflikt nabierał coraz większej intensywności i nie dawał szans na pokojowe rozwiązanie.

$\mathrm{Z}$ trzech monografii poświęconych tym wydarzeniom i wydanych w ostatnich latach, największą wartość reprezentuje książka Olega Romańki. Co jest rzadkością wśród dzisiejszych historyków XX w. z Rosji i Ukrainy, Romańko jest uznawany na całym świecie za jednego z najlepszych specjalistów w swojej dziedzinie ${ }^{6}$. Monografie jego tworzone są na podstawie szerokiej kwerendy archiwalnej (archiwa Ukrainy, Rosji, Białorusi, Niemiec i Polski) i znajomości najnowszej literatury przedmiotu w kilku językach. Dotyczy to także omawianej pracy; godne podkreślenia jest zwłaszcza oparcie pracy na materiałach niemieckich.

Książka składa się z sześciu rozdziałów i zakończenia. Rozdział pierwszy dotyczy miejsca Krymu w przedwojennych doktrynach narodowo-socjalistycznych oraz $\mathrm{w}$ planach wojskowych i polityków z okresu wojny. Romańko pokazuje, że nie istniała wśród decydentów III Rzeszy jedna obowiązująca doktryna nie tylko wobec Krymu, ale i przyszłości całych okupowanych terytoriów ZSRS. Ten stan prowizorium utrzymał się do końca okupacji półwyspu, a polityka władz (wojskowych, policyjnych i cywilnych) była wypadkową różnych koncepcji dochodzących do głosu w różnych momentach i kręgach decyzyjnych. Rozdział drugi przybliża czytelnikowi fenomen masowej kolaboracji tzw. narodów wschodnich z Niemcami w czasie wojny. Choć nie odnosi się on bezpośrednio do Krymu, jest ważny dla oceny militarnego zaangażowania Tatarów Krymskich po stronie niemieckiej na tle innych narodów. W rozdziałach trzecim i czwartym opisane są: organizacja niemieckiej i kolaboracyjnej administracji na Krymie, funkcjonowanie struktur policyjnych i wojskowych, funkcjonowanie propagandy oraz komitetów narodowych (poza tatarskimi pewną aktywność wykazywali także Ormianie i Bułgarzy), a także mechanizmy polityki władz niemieckich wobec poszczególnych narodowości ze szczególnym uwzględnieniem Tatarów. Romańko dokładnie opisał również proces formowania oddziałów tatarskich oraz rolę, jaką pełniły one w systemie okupacyjnym. Niezwykle ważne jest odtworzenie faktycznej liczebności tych oddziałów i ocena ich wartości bojowej, oparte na materiałach niemieckich, co pozwala na obiektywną ocenę skali tego zjawiska. Rozdział piąty poświęcony jest formacjom złożonym z przedstawicieli narodów kaukaskich i Azji Centralnej w służbie niemieckiej oraz próbom werbunku Rosjan na Krymie do pododdziałów Rosyjskiej Armii Wyzwoleńczej. Powiązany jest on tematycznie z rozdziałem drugim i tylko częściowo odnosi się do przebiegu wydarzeń na Krymie. Wreszcie rozdział szósty skrótowo opisuje politykę Moskwy wobec Krymu w czasie wojny, aktywność par-

6 Zajmuje się głównie kwestią kolaboracji tzw. narodów wschodnich z Niemcami w czasie II wojny światowej (formacjami rosyjskimi, białoruskimi, tatarskimi, hinduskimi i złożonymi z przedstawicieli narodów Azji Centralnej) oraz funkcjonowaniem ziem białoruskich pod okupacją niemiecką. Część jego prac ukazała się w USA w języku angielskim. 
tyzantki sowieckiej oraz próby pozyskania oddziałów obcoplemiennych w służbie niemieckiej, w obliczu nadciągającej ofensywy Armii Czerwonej.

Wielką zaletą książki jest rzetelne opracowanie tematu wojskowej kolaboracji Tatarów z Niemcami i kluczowego zagadnienia ich udziału w walce z partyzantką sowiecką. Napisano na ten temat już bardzo dużo (zwłaszcza w czasach ZSRS), ale publikacje te w większości były czystą propagandą kształtującą obraz Tatara-zdrajcy. Romańko oszacował liczbę Tatarów, którzy przewinęli się przez formacje służące u boku Niemców w latach 1941-1944, na ok. 20000 ludzi (w policji pomocniczej, w Wehrmachcie i formacjach przeciwpartyzanckich). Pod względem ilościowym, było to zaangażowanie zbliżone do udziału Białorusinów, Gruzinów czy Ormian w walkach po stronie niemieckiej. Biorąc jednak pod uwagę liczebność całego narodu (ok. 220000 ludzi), trzeba przyznać, że proporcjonalnie odsetek ten był bardzo wysoki i Niemcom udało się praktycznie w całości wykorzystać możliwości mobilizacyjne Tatarów ${ }^{7}$. Autor pisze o tym w sposób obiektywny i daleki od zaangażowania publicystycznego, bez używania określeń typowych dla sowieckiej propagandy („zdrajcy”, „faszyści” itp.), pojawiających się też często we współczesnych publikacjach. Jednocześnie w żaden sposób nie gloryfikuje oddziałów tatarskich i nie kreuje ich na bohaterów walki z bolszewizmem. Podejście takie jest rzadkością we współczesnych publikacjach rosyjskich czy ukraińskich, które zwykle są bardzo spolaryzowane i nie kryją się z sympatią do jednej albo drugiej opcji ideologicznej.

Romańko stara się przybliżyć pobudki, które pchnęły Tatarów do współpracy z Niemcami - począwszy od fatalnych warunków panujących w obozach jeńców, z których wywodził się spory odsetek „dobrowolców”, poprzez powszechną w społeczeństwie tatarskim niechęć do władzy sowieckiej datującą się od 1918 r., skończywszy na brutalizacji wojny partyzanckiej i konieczności opowiedzenia się ludności cywilnej po jednej ze stron. Wspomina także o krótkim epizodzie państwowości krymskiej z 1918 r. i o podejmowanych przez przywódców tatarskich (krajowych i emigracyjnych) próbach realizacji postulatów politycznych w zamian za współpracę wojskową. Romańko stawia przy tym ciekawą tezę, że wydarzenia w wielu rejonach ZSRS okupowanych przez Niemców spełniają kryteria wojny domowej. Konflikt dwóch grup miejscowych na podłożu politycznym i etnicznym przy udziale czynnika zewnętrznego na Krymie doskonale je spełniał. Zgodzić się można $\mathrm{z}$ twierdzeniem, że „kolaboracja na okupowanych terenach ZSRS była faktycznie przedłużeniem wydarzeń wojny domowej lat 1918-1920, a jej przyczyny tkwiły w specyfice przemian społeczno-politycznych, przeprowadzonych w przedwojennym ZSRS. Należy tutaj wymienić represje, kolektywizację, prześladowania religijne itd." (s. 32).

7 Na s. 330 Romańko podaje szacunkowe liczby ilustrujące zaangażowanie Tatarów po obu walczących stronach. W 1941 r. do Armii Czerwonej zmobilizowano ich ok. 10 000, z których część bądź zdezerterowała, bądź trafiła do niewoli. Wg oficjalnych danych sowieckich w okresie 1941-1944 przez oddziały partyzanckie przewinęło się ok. 12000 ludzi, z czego Tatarów Krymskich ok. 1100. W konspiracji sowieckiej było aktywnych ok. 2500 osób, z czego Tatarów poniżej 100. 
Książka pozostawia jednak pewien niedosyt. Przede wszystkim jej tytuł jest postawiony jakby trochę na wyrost - praca dotyczy w zasadzie problemu kolaboracji Tatarów Krymskich w latach 1941-1944, nawet kwestia kolaboracji pozostałych narodowości (zwłaszcza w działalności administracji, samorządów, funkcjonowania kołchozów i przemysłu, szkolnictwa itp.) jest tylko zarysowana. W ogóle nieobecne są zagadnienia eksploatacji gospodarczej Krymu, tak ważne dla poznania jego roli w niemieckim systemie okupacyjnym. Sprawy funkcjonowania szkolnictwa, odrodzenia życia religijnego, kultury czy warunków życia ludności cywilnej są albo pominięte, albo ledwie wspomniane na marginesie wiodącego tematu. Tylko niewielkie wzmianki poświęcone są tematowi represji Niemców wobec ludności cywilnej i zwłaszcza eksterminacji ludności żydowskiej ${ }^{8}$. Za to zupełnie niepotrzebne są wyczerpujące opisy (prawie 100 stron) procesu tworzenia formacji kolaboracyjnych na terenie innych republik związkowych i użycia ich przez Niemców na wszystkich frontach II wojny światowej, co z Krymem miało niewiele wspólnego. Wątek ogólnych tendencji w zakresie całego ZSRS, jakkolwiek bardzo istotny dla pokazania skali kolaboracji Tatarów na tle innych narodów, mógł zostać zarysowany na kilku-kilkunastu stronach. Wspomniane zupełne pominięcie kilku kluczowych zagadnień i sztuczne wstawienie dużej partii tekstu nieodnoszącej się bezpośrednio do Krymu sprawiają wrażenie, jakby książka była przygotowana w pośpiechu i jej konstrukcja nie została do końca przemyślana.

Jeżeli chodzi o wiodący temat kolaboracji Tatarów Krymskich, to nacisk położony jest na formowanie oddziałów tatarskich oraz na działalność tzw. komitetów muzułmańskich i próby utworzenia za ich pomocą reprezentacji politycznej mogącej prowadzić negocjacje z Niemcami. Temat walki z partyzantką poruszany jest bardzo często, pozostaje jednak jakby tylko tłem. Książka Romańki niestety nie udziela odpowiedzi na pytania, jakie znaczenie militarne faktycznie miała partyzantka sowiecka na Krymie, jakie były jej realne sukcesy, czy posiadała sprawne zaplecze wywiadowcze, wreszcie z jaką intensywnością toczyły się walki w górach. Obraz jej „dokonań" został ukształtowany przez sowiecką propagandę i na Krymie utrzymuje się powszechnie do dzisiaj, stając się jednym z mitów założycielskich sowieckiego i rosyjskiego Krymu, najważniejszym obok wojny krymskiej oraz rewolucji 1905 i 1917. Temat działalności sowieckiej partyzantki krymskiej w latach 1941-1944 czeka jeszcze na rzetelne opracowanie, do którego niezbędna byłaby kwerenda $\mathrm{w}$ archiwach rosyjskich, ukraińskich, niemieckich i rumuńskich.

Podobne uwagi dotyczą kwestii eksterminacji Żydów i Krymczaków. O ile sam przebieg Zagłady na Krymie jest w ogólnym zarysie znany, o tyle jednak ciągle mało wiemy o postawach ludności półwyspu wobec tej tragedii. Duża część policji pomocniczych i oddziałów „obcoplemiennych” brała udział w Holokauście na Wschodzie i oskarżenia ich o zbrodnie wojenne (w dużym stopniu uzasadnione) były bardzo

8 Przykładem świetnego opracowania obejmującego wszystkie najważniejsze zagadnienia związane $\mathrm{z}$ funkcjonowaniem reżimu okupacyjnego na szczeblu regionalnym jest książka Alexandra Dallina Odessa 1941-1944. A Case Study of Soviet Territory under Foreign Rule, Iaşi 1998. 
chętnie wykorzystywane przez propagandę sowiecką. Co ciekawe, w przypadku jednostek tatarskich wątek ten pojawia się rzadko, nawet w pracach autorów prezentujących opcję prosowiecką/prorosyjską. Romańko wspomina o użyciu jednego $\mathrm{z}$ batalionów tatarskich do pilnowania obozu koncentracyjnego pod Symferopolem, kilka innych pododdziałów pełniło bliżej niesprecyzowane funkcje „ochronne” czy „wartownicze”. Żadnych konkretnych przypadków udziału jednostek tatarskich w egzekucjach nie wymienia, czego jednak nie można wykluczyć.

W odróżnieniu od pracy Romańki książka Andrieja Malgina jest typowym przykładem współczesnej historiografii rosyjskiej, wyrosłej z tradycji sowieckiej i reprezentującej „wielkorosyjski” punkt widzenia na historię Europy Wschodniej XX wieku. Malgin jest dyrektorem Centralnego Muzeum Taurydy w Symferopolu (najstarszej i największej placówki muzealnej Krymu) oraz publicystą, autorem licznych publikacji dotyczących współczesnej Ukrainy ${ }^{9}$ i osobą często pojawiającą się w krymskich mediach. W swojej publicystyce jest wyraźnie wrogi wobec ukraińskiego ruchu narodowego i zawzięcie krytykuje wszelkie próby unifikacji państwa, przychylnie patrząc na ideę „wspólnej przestrzeni cywilizacyjnej” łączącej większość regionów Ukrainy z Rosją. Jego poglądy znajdują też odbicie w działalności Muzeum Taurydy, gdzie dominuje specyficzna mieszanka narracji sowieckiej i imperialno-rosyjskiej.

Omawianej książki nie można jednak zupełnie odrzucić i traktować jako utworu czysto propagandowego - uplasowałbym ją raczej na pograniczu literatury naukowej i publicystyki. Chociaż napisana $\mathrm{z}$ wyraźnie prosowieckiego punktu widzenia, pozwala czytelnikowi przynajmniej w kilku aspektach poznać mechanizmy, które doprowadziły do eskalacji konfliktu na tle etnicznym na Krymie i w efekcie do deportacji Tatarów w 1944 r. Malgin bazuje na dokumentach sztabu partyzanckiego znajdujących się w symferopolskim archiwum; nie korzysta przy tym z literatury obcojęzycznej (za wyjątkiem pojedynczych publikacji przetłumaczonych na język rosyjski) ani z dokumentów niemieckich. Poważne wątpliwości budzi częste sięganie do wspomnień partyzantów sowieckich, publikowanych w latach 50., 60. i 70., które raczej trudno uznać za wiarygodne źródło. W warstwie faktograficznej jego praca nie przynosi nic ponad ustalenia Romańki, nie ma w niej rażących błędów czy podawania nieprawdziwych faktów, problemem jest raczej interpretacja i ocena wydarzeń.

Malgin ogranicza się wyłącznie do spojrzenia na wydarzenia lat 1941-1944 oczyma Moskwy, zupełnie nie uwzględniając punktu widzenia Tatarów ani polityki niemieckiej na półwyspie. Nie bierze nawet pod uwagę, że Tatarzy ponieśli $\mathrm{z}$ rąk sowieckich duże straty w wyniku wojny domowej, głodu, kolektywizacji oraz czystek inteligencji w latach 30. i w większości nie utożsamiali się z ZSRS, a zatem

9 Poza artykułami godna uwagi książka Украина: соборность и регионализм (Symferopol 2005) - manifest przekształcenia Ukrainy w federację regionów napisany po pomarańczowej rewolucji i krytykujący oba główne nurty polityczne kraju reprezentowane przez Juszczenkę i Janukowicza.

Nie należy mylić autora omawianej książki, Andrieja Witaliewicza, ze starszym o kilka lat Andriejem Wiktorowiczem Malginem, rosyjskim dziennikarzem i krytykiem literackim. 
dyskusyjne jest nazywanie ich zdrajcami ojczyzny. Nie próbuje w wyważony sposób ocenić działalności polityków tatarskich, tak emigracyjnych, jak i krajowych, usiłujących prowadzić grę polityczną z Niemcami i nie będących jedynie kolaboracyjnymi kreaturami działającymi z najniższych pobudek.

Jako przykład spojrzenia autora na najbardziej sporne kwestie można podać opis realiów konfliktu pomiędzy partyzantką a tatarską wsią. Malgin oskarża „dobrowolców" o stosowanie zbiorowej odpowiedzialności i zbrodnie wojenne, podczas gdy partyzanci rzekomo starali się nawrócić Tatarów poprzez ulotki, podziemną prasę i agitację ustną (!), uciekając się do egzekucji tylko w przypadkach ewidentnej kolaboracji. Zresztą, jak pisze, „dzisiaj, ponad pół wieku po tych wydarzeniach, bardzo łatwo mówić o błędach albo niedostatecznym dżentelmeństwie [недостаточном джентльменстве] partyzantów. Ciekawe, jakby zachowali się dzisiejszy krytycy w warunkach podobnych do tych, w których znaleźli się partyzanci Krymu, okrążeni regularnymi, po wielokroć liczniejszymi oddziałami przeciwnika, pozbawieni zaopatrzenia i otoczeni, mówiąc delikatnie, niezbyt przyjazną im ludnością" (s. 59-60).

Punkt ciężkości książki leży jednak nie tyle w afirmacji sowieckiej partyzantki, ile w podejściu do tytułowej „kwestii tatarskiej”, co ma swoje drugie dno w dzisiejszej sytuacji na Krymie. Tatarzy - uważa Malgin - począwszy od odwilży z połowy lat 50., prowadzili zorganizowaną kampanię, w której przedstawiali się jako ofiara fałszywych oskarżeń. Utrzymywali, że ich uczestnictwo w sowieckim ruchu partyzanckim i konspiracji było przez władze celowo pomniejszane, odsetek kolaborantów tatarskich - celowo powiększany, a stosunkowo rzadkie przypadki kolaboracji spowodowane były brutalną postawą samych partyzantów. Po fali powrotów Tatarów na Krym w latach 90. doszło rzekomo do dalszego fałszowania historii przez tatarskich publicystów, którzy to zaczęli propagować obraz „niewinnych ofiar” i ich „katów”. Co więcej, według Malgina na tej fali doszło do „swoistej rehabilitacji współpracowników faszystów", czego przykładem miało być uroczyste przeniesienie do Bachczysaraju prochów Ameta Ozenbaszłego i Edige Kyrymała, dwóch polityków tatarskich aktywnych w latach 1941-1944. Wyjaśnienie wspomnianych kwestii spornych (tj. rzeczywistego udziału poszczególnych narodowości Krymu w sowieckim ruchu oporu i w kolaboracji z Niemcami) jest według autora niezbędne do prowadzenia na współczesnym Krymie poważnej dyskusji historycznej. Podejście do tego tematu jako "tabu” i wyjątkowo delikatne traktowanie Tatarów w obawie przed wywołaniem „napięć na tle etnicznym” nie może mieć miejsca. W przeciwnym razie, argumentuje Malgin, „zawsze będzie możliwe manipulowanie prawdą przy takiej czy innej koniunkturze politycznej. Wyjaśnienie tych spraw potrzebne jest nie tylko Tatarom Krymskim, ale i całemu krymskiemu społeczeństwu, ponieważ współżycie nie może być oparte na niedomówieniach i wzajemnych podejrzeniach".

Ocena Malgina jest jednoznaczna - skala poparcia Tatarów dla Niemców była bardzo wysoka, zwłaszcza jeśli chodzi o ich uczestnictwo w walce z partyzantką. Trudno z tym polemizować, zwłaszcza po publikacji książki Romańki, pozostaje jednak kwestia oceny deportacji 1944 r. Autor wprawdzie zastrzega się, że nie można 
mówić o jakimkolwiek usprawiedliwieniu deportacji przeprowadzonej na zasadzie zbiorowej odpowiedzialności, ale jednocześnie dodaje, że nie może to prowadzić do automatycznego usprawiedliwienia kolaboracji czy jej negowania. Jednocześnie protestuje przeciwko twierdzeniom wielu historyków tatarskich czy zachodnich o systematycznej rosyjskiej polityce antytatarskiej prowadzonej na Krymie przez Rosję od końca XVIII w. W świetle tych teorii polityka caratu doprowadziła do kilku wielkich fal emigracji Tatarów z Krymu w ciągu XIX w., zmieniła w ciągu 100 lat strukturę narodowościową półwyspu oraz przyczyniła się do zubożenia rdzennej ludności pozostałej na miejscu; kontynuacją była działalność bolszewików w czasie wojny domowej oraz w latach 20. i 30., a „ukoronowaniem” stała się deportacja 1944 r. zupełnie rozwiązująca „kwestię tatarską” na Krymie. Malgin stanowczo protestuje przeciwko takiemu spojrzeniu na historię półwyspu - sprowadza się to według niego do „prymitywnego schematu «niewinnych ofiar» $\mathrm{i}$ «oczywistych oprawców», co w efekcie przekłada się na dzisiejszą sytuację na Krymie i karmi wszelkie konflikty i napięcia na tle etnicznym". Podkreśla, że decyzja o deportacji $1944 \mathrm{r}$. miała charakter indywidualny i ściśle zdeterminowany wydarzeniami ostatnich trzech lat oraz „nie była powiązana ani z polityką Imperium Rosyjskiego, ani z polityką narodowościową ZSRS lat 20. i 30." (cytaty - s. 5-7).

Książka Bekirowej jest zarysem historii politycznej Tatarów Krymskich w latach 1941-1991 i wydarzeniom okresu II wojny światowej poświęcony jest tylko jej pierwszy rozdział stanowiący tło dla opisu wydarzeń lat późniejszych. Nie będzie chyba wielką przesadą stwierdzenie, że rozdział ten jest odwróceniem tez książki Malgina.

Autorka przedstawia obraz wydarzeń lat 1941-1944 oparty na kilku najważniejszych założeniach. Przede wszystkim konsekwentnie zaniża liczbę Tatarów w służbie niemieckiej, powołując się na duże rozbieżności w ustaleniach wśród historyków; poza tym podkreśla, że w jednostkach nazywanych umownie tatarskimi czy ochotniczymi służyli przedstawiciele różnych narodowości Krymu ${ }^{10}$. Bekirowa dodatkowo podważa ochotniczy charakter oddziałów tatarskich w służbie niemieckiej, przywołując ciężkie warunki w niemieckich obozach jenieckich (przemilcza przy tym, że większość żołnierzy formacji tatarskich stanowili jednak ochotnicy napływający bezpośrednio z Krymu). Jako dowód tego, że ochotniczy charakter tych formacji stał pod znakiem zapytania, podaje liczne rzekomo przypadki współpracy żołnierzy tatarskich z sowieckim podziemiem.

Dalej Bekirowa stwierdza, że lojalność Tatarów Krymskich wobec Niemców została im przypisana zbiorowo, zarówno przez okupantów (trochę - jak sugeruje - na wyrost), jak i przez kierownictwo partyzantki sowieckiej (s. 48-9). W rzeczywistości postawy Tatarów były niejednorodne i wyraźnie można było wyróżnić wśród

10 Najlepszy przykład żonglerki danymi na s. 68 - stwierdzenie, że na ok. 150 wsi tatarskich oddziały były sformowane tylko w 20-25, ale autorka nie zwraca przy tym uwagi, że miały one charakter zbiorczy i były skoncentrowane w wybranych punktach. Podobnie s. 73 - przeszacowane inne oddziały obcoplemienne, obniżone stany batalionów tatarskich. Wspomniane represje wobec ludności cywilnej na przykładzie obozu w kołchozie „Krasnyj” (s. 72), bez wzmianki o pilnującym go 152. tatarskim batalionie. 
nich trzy główne grupy: 1) niewielką grupę działaczy (przeważnie emigracyjnych) marzących o reaktywacji państwa tatarskiego przy pomocy Niemców, osób rozczarowanych władzą sowiecką i kolaborantów-koniunkturalistów; 2) komunistów tatarskich; 3) zdecydowaną większość społeczeństwa, sterroryzowaną i zmuszoną do wykonywania zarządzeń władz okupacyjnych. Rozwijając tę tezę autorka dochodzi do wniosku, że Tatarzy byli jednym z kilku narodów okupowanego Krymu, tak samo cierpiącymi od Niemców jak inni. Terror do tego był podwójny - ludność wsi pogórza cierpiała nie tylko ze strony okupantów, ale i partyzantów i ta sytuacja rodziła konieczność dokonywania jednoznacznych wyborów, które okazały się tragicznie w skutkach (s. 57). Bekirowa wprawdzie przyznaje, że Tatarzy byli postrzegani przez Niemców jako potencjalni sojusznicy i ludność drugiej kategorii (po Niemcach i Bułgarach krymskich) oraz że największą nieufność przejawiano wobec Rosjan, ale podkreśla, że takie stwierdzenie jest prawdziwe tylko do połowy $1942 \mathrm{r}$. Potem rzekomo Tatarów Krymskich przestano uważać za wiarygodnych sojuszników, a starania Niemców obróciły się głównie w kierunku pozyskania miejscowych Rosjan i ich werbunku do oddziałów tworzonych pod egidą Własowa.

Próbując określić przyczyny klęski partyzantki sowieckiej w pierwszym okresie jej działalności, Bekirowa podkreśla splot różnych przyczyn: niekorzystne warunki terenowe (niewielki, izolowany obszar górski), fatalną organizację baz zaopatrzeniowych (zrabowanych bez trudu przez okolicznych mieszkańców niezależnie od narodowości), wreszcie niechęć do Tatarów kierownictwa partyzantki, co miało popchnąć część ludności do kolaboracji „dla obrony od «wizyt» partyzantów” (s. 54-6). Przy tym wszystkim autorka akcentuje poparcie dużej części wsi pogórza dla partyzantki i udział Tatarów w konspiracji sowieckiej, co ma niewiele wspólnego z rzeczywistością zwłaszcza w odniesieniu do pierwszych dwóch lat okupacji.

Stosunek autorki do deportacji 1944 r. jest jednoznaczny - nie była ona ani niezbędna dla oczyszczenia Krymu od okupantów, ani uzasadniona postawą „garstki” Tatarów w czasie okupacji. Stawia ona przy tym pytanie o genezę tej decyzji i jej znaczenie dla decydentów ZSRR, na które trudno dziś odpowiedzieć bez dostępu do najważniejszych dokumentów z archiwów rosyjskich. Czy deportacja $1944 \mathrm{r}$. była tylko aktem zemsty, czy też wykorzystaniem okazji, jaką przyniosła okupacja niemiecka dla oczyszczenia Krymu z Tatarów, co było od dawna celem polityki rosyjskiej $\mathrm{w}$ regionie?

Reasumując, Bekirowa daleka jest od przyjęcia cytowanego założenia Olega Romańki - „władza sowiecka [przed 1941 r.] zrobiła wszystko, co można było zrobić dla wywołania kryzysu lojalności wobec siebie wśród Tatarów Krymskich" - co moim zdaniem najlepiej oddaje przyczyny takiej, a nie innej ich postawy w momencie załamania się państwa sowieckiego. Autorka zdaje się wypierać fakt, że szerokie kręgi społeczeństwa tatarskiego były jednoznacznie przeciwne komunistom, a działacze emigracyjni i krajowi starali się realizować politykę mającą na celu oderwanie Krymu od ZSRS, odwołując się przy tym do tradycji z lat 1917-1918. Jej wizja historii Tatarów Krymskich nie jest próbą przedstawienia tych zmagań w całej swojej 
złożoności, a zaledwie próbą odparowania oskarżeń o kolaborację w sposób trochę podobny do komunistów tatarskich $\mathrm{z}$ lat 50.-80. Narracja ta w dużym stopniu opiera się na odwołaniu do ofiar poniesionych przez naród tatarski w walce $\mathrm{z}$ „faszyzmem”, na podkreśleniu licznej obecności Tatarów w szeregach Armii Czerwonej i ruchu oporu, wreszcie na zwróceniu uwagi na niesprawiedliwość deportacji, która dotknęła także tysięcy czerwonoarmistów, ideowych komunistów i ich rodzin.

Książki Malgina i Bekirowej prezentują zatem dwa punkty widzenia na historię Krymu okresu II wojny światowej, przy czym należy je rozpatrywać nie jako głosy historyków, a bardziej jako reprezentację dwóch obozów politycznych walczących ze sobą z wykorzystaniem na wielką skalę oskarżeń historycznych. Optyka prosowiecka i jednocześnie prorosyjska zdecydowanie dominuje dzisiaj na Krymie i nic nie wskazuje, żeby sytuacja ta miała się zmienić w dającej się przewidzieć przyszłości. Programy szkolne, cała sfera symboliczna (pomniki, nazwy ulic i miejscowości, obchody rocznicowe itp.) i ogólny profil mediów krymskich przedstawiają historię półwyspu w kategoriach ustalonych przez komunistów po II wojnie światowej w myśl hasła „takich ofiar, jakie poniosła Rosja za Krym, nie poniosła za żaden swój region" ${ }^{11}$. Centralnym elementem tego schematu jest Wielka Wojna Ojczyźniana (nienazywana nigdy II wojną światową), a jej symbolami są obrona Sewastopola oraz działalność krymskiej partyzantki. Cała literatura sowiecka dotycząca tych wydarzeń nie została poddana krytycznej analizie i jest powszechnie akceptowana, co dotyczy także wytworzonego przez nią stereotypu Tatara-zdrajcy i renegata w służbie hitlerowskiej. Co więcej, zamieszkujący Krym Rosjanie i Ukraińcy przez wiele lat nie mieli styczności z Tatarami i bardzo często zetknęli się z nimi pierwszy raz w życiu na początku lat 90., gdy ci wrócili z miejsc deportacji w Azji Centralnej, próbując ułożyć sobie życie na Krymie od nowa. Próby odzyskania przez nich miejsc ważnych dla swojej historii (np. pałac w Bachczysaraju), cmentarzy, świątyń itd. czy wykupienia domów (zwrot skonfiskowanej własności prywatnej nie wchodził w grę) wywołały szereg napięć, często sztucznie podsycanych przez lokalnych polityków i media z odwołaniem się do wydarzeń sprzed 50 lat.

11 Tę dominację symboliczną najlepiej widać w nazewnictwie miejscowości i ulic. Władze sowieckie w II połowie lat 40 . usunęły prawie wszystkie stare nazwy geograficzne mające tatarskie pochodzenie i zastąpiły je zupełnie nowymi o „słowiańskim” brzmieniu. Nazewnictwo to utrzymało się z nielicznymi wyjątkami do dzisiaj. Podobnie wygląda sprawa z nazwami ulic - wszędzie utrzymały się ulice Lenina, Dzierżyńskiego, Sowiecka itp., a tatarskimi patronami są przeważnie komuniści bądź bohaterowie Armii Czerwonej (na czele z Amet-Chan Sułtanem, asem sowieckiego lotnictwa myśliwskiego w II wojnie światowej). Nie zmieniono np. ulic Alieksieja Mokrousowa, pierwszego dowódcy partyzantki sowieckiej w latach 1941-1942, odwołanego przez Moskwę ze względu na prowadzenie zbyt brutalnej polityki wobec Tatarów podsycającej ich niechęć do ZSRS, osoby odpowiedzialnej za szereg masowych egzekucji na Krymie w latach 1917-1920.

Paradoksem jest fakt, że w Symferopolu ulica Ismaila Gasprinskiego (ojca-założyciela nowoczesnego tatarskiego ruchu narodowego z końca XIX w.) krzyżuje się właśnie z ulicą Mokrusowa. Druga na Krymie ulica Gasprinskiego znajduje się na przedmieściach Bachczysaraju i jest przedłużeniem ulicy Lenina. 
Tatarzy stanowią aktualnie ok. 10\% ludności Krymu i mimo tego, że są stosunkowo dobrze zorganizowaną społecznością, trudno im podjąć dyskusję o rewizję dominującego obrazu historii XX w. Wszelkie tego typu próby są zawzięcie atakowane przez miejscowych rosyjskich polityków i publicystów, często z poparciem Cerkwi prawosławnej i różnych organizacji społecznych (np. powstających w ostatnich latach jak grzyby po deszczu wspólnot kozackich). Poza tym wspólczesna tożsamość Tatarów Krymskich ukształtowała się w latach powojennych w Azji Centralnej, w warunkach ścisłej kontroli państwowej, a wpływ emigracji na ich życie polityczne po 1991 r. był niewielki. Powojenna walka o rehabilitację przez długi czas była staraniem grupy komunistów tatarskich i osób biorących udział w II wojnie światowej po stronie sowieckiej, sprzeciwiających się traktowaniu jako zdrajców ojczyzny. Ich głównym argumentem za otwarciem drogi powrotnej na Krym i przywróceniem autonomii było odwołanie do leninowskich zasad polityki narodowościowej z lat 20. Dopiero pokolenie aktywistów działających w latach 70 . i 80., po nawiązaniu kontaktu z dysydentami moskiewskimi, zaczęło ewoluować $\mathrm{w}$ kierunku antykomunistycznym, przy czym ta zmiana ideologiczna nie równała się automatycznemu nawiązaniu do tradycji Milli Firka z okresu 1917-1918 ani emigracji usiłującej wykorzystać ruch prometejski lub III Rzeszę do wywalczenia niezależności półwyspu. Te dwa czynniki są więc decydujące dla ukształtowania narracji własnej historii XX w. u Tatarów, w której położony jest nacisk bardziej na odpieranie zarzutów „opcji rosyjskiej”, niż na bezpośrednie odwołanie się do prób wybicia się na niezależność z okresu 1917-1918 i 1941-1944.

Reasumując, z jednej strony mamy książkę sztandarową dla dominującego nurtu patrzenia na kluczowe wydarzenia II wojny światowej, wydaną przy finansowej pomocy Komunistycznej Partii Ukrainy, napisaną przez osobę zajmującą jedno z najważniejszych stanowisk w dziedzinie nauki i kultury na Krymie. Z drugiej mamy książkę Bekirowej będącą reakcją na oskarżenia tego głównego nurtu i elementem polityki mniejszości tatarskiej dążącej do „neutralizacji negatywnych stereotypów (...) wytworzonych w okresie sowieckim i (...) cały czas podtrzymywanych przez tych, którzy nie mogą pogodzić się z myślą, że jedyną ojczyzną Tatarów Krymskich jest Krym" ${ }^{\prime 2}$. Spór ten jest na tyle intensywny i upolityczniony, że niestety zagłusza zupełnie głosy nielicznych fachowców, jak Oleg Romańko ${ }^{13}$.

W tej sytuacji pozostaje tylko zachęcić polskich historyków do większego zainteresowania dziejami Krymu. Prace kilku zachodnich (przeważnie amerykańskich) historyków regionu czarnomorskiego pokazują, że zmierzenie się z historią regionu przez osobę z zewnątrz, nieuwikłaną w bieżące, lokalne spory i mającą przywilej spojrzenia z oddali, może przynieść ciekawe rezultaty i stać się impulsem dla rozwoju miejscowej historiografii.

12 Cytat ze strony www.kirimtatar.com, której Bekirowa jest jedną z autorek.

13 Co ciekawe ten ceniony historyk, mający na swoim koncie wiele monografii wydanych w USA i Moskwie, pracuje jako wykładowca w Akademii Medycznej w Symferopolu, a nie w Uniwersytecie Taurydzkim, największej uczelni regionu. 


\section{Latest publication on history of the Crimea during World War II}

A period of German occupation of the peninsula between 1941 and 1944, during which Crimean Tartars started a military cooperation with Germany, is a key component of Crimea history in the 20th century. The cooperation was mainly directed against Soviet guerrillas stationing in the Crimean Mountains during the occupation. Due to the collaboration, Stalin made up a decision to deport all Tartars from the Crimea in autumn 1944.

The paper presents Oleg Romańko, Andriej Malgin and Gulnara Bekirowa's publications. While Romańko's monograph is a balanced attempt of a description and an evaluation of military and political collaboration of Crimean Tartars, the remaining works should be examined in terms of a current political dispute in the Crimea. Both Malgin's book, published with the support of the Communist Party of Ukraine, and Bekirowa's work, who was a researcher and a social activist of Tatar nationality, can be classified as scientific literature and journalism. Malgin shows a typical Soviet-Russian narration of Crimean history particularly hostile towards Tatars. However, Bekirowa's work contains typical arguments of Tatars defence against allegations of collaboration. Those opinions are characteristic to the current political situation in the Crimea, where the Soviet-Russian concept of history prevails in the public sphere, and a large number of peninsula's citizens treat the Tatar minority reluctantly.

Limitations, which hinder work of independent historians on the peninsula, are also discussed in the article. Such a situation, with a small number of valuable publications on Crimea history of the 20th century, shall be of interest to researchers from Western and Central Europe.

Works of several western (mostly American) historians of the Black Sea region show that facing the regional history by a strange person, not entangled in current disputes and having a chance to look from a distance, can bring interesting results and become an impulse to a development of local historiography.

Translated by Marta Antoniuk

\section{Новейшие публикации, касающиеся истории Крыма в период Второй мировой войны}

Ключевым фрагментом истории Крыма XX в. является период немецкой оккупации полуострова в 1941-44 гг., во время которой крымские татары начали в большом масштабе военное сотрудничество с немцами. Оно было направлено, в первую очередь, против советских партизанских отрядов, действовавших в Крымских горах весь период оккупации. Коллаборационизм послужил Сталину предлогом для принятия решения о депортации всех татар из Крыма весной 1944 г.

Статья представляет три самые новые публикации, касающиеся этого вопроса, за авторством Олега Романько, Андрея Мальгина и Гульнары Бекировой. Насколько монография Романько является попыткой взвешенного описания и оценки явления военного и политического коллаборационизма крымских татар, настолько остальные две работы надо рассматривать в контексте текущего политического спора в Крыму. Так, книгу Мальгина, изданную при содействии Коммунистической Партии Украины, как и работу Бекировой, исследователя и общественного деятеля татарской национальности, можно классифицировать как нечто среднее между научной литературой и публицистикой. Мальгин представляет типичное советско-российское повествование об истории Крыма, решительно враждебное к татарам. Работа Бекировой, в свою очередь, содержит типичные аргументы защиты татар против обвинений в коллаборационизме, выработанные еще в советский период татарскими коммунистами. Эти голоса характерны для нынешней 
политической обстановки в Крыму, где в публичной сфере преобладает советско-российское видение истории, а большая часть населения острова относится к татарскому меньшинству с неприязнью.

В статье были отмечены ограничения, которые в большой степени блокируют работу независимых историков на полуострове. Такая обстановка при небольшом числе ценных изданий на тему крымской истории ХХ в. должна вызвать интерес у исследователей из Западной и Центральной Европы. Работы нескольких западных (преимущественно американских) историков Причерноморья доказывают, что если непростую историю региона исследует человек извне, не вовлеченный в текущие споры и обладающий привилегией взгляда издалека, то это может принести интересные результаты и оказаться импульсом для развития местной историографии.

Перевод Агнешка Поспишыль

\section{Bibliografia}

Alexander Dallin, Odessa 1941-1944. A Case Study of Soviet Territory under Foreign Rule, Iaşi 1998. Alan Fisher, Between Russians, Ottomans and Turks: Crimea and Crimean Tatars, Istanbul 1998. Alan Fisher, The Crimean Tatars, Stanford 1978.

Гульнара Бекирова, Крымские Татары 1941-1991, Симферополь 2008.

Александр Г. Зарубин, Вячеслав Г. Зарубин, Без победителей. Из истории Гражданской войны в Крыму, Симферополь 2008.

Михаил Кизилов, Крымская Иудея. Очерки истории евреев, хазар, караимов и крымчаков в Крыму с античных времен до наших дней, Симферополь 2011.

Андрей В. Мальгин, Партизанское движение Крыма и «татарский вопрос» 1941-1944, Симферополь 2009.

Андрей В. Мальгин, Украина: соборность и регионализм, Симферополь 2005.

Население Крыма в конце XVIII - конце XX веков, ред. Я. Е. Водарский, Москва 2003.

Олег В. Романько, Крым под пятой Гитлера. Немецкая оккупационная политика в Крыму 1941-1944 г2., Москва 2011.

www.kirimtatar.com

Jakub Ber, doktorant w Zakładzie Historii Społecznej XIX i XX w. w Instytucie Historii PAN im. T. Manteuffla, przygotowuje pracę doktorską na temat historii Besarabii pod rządami rumuńskimi w latach 1918-1940. 